\title{
'n NUWE PERSPEKTIEF OP DIE SAAMLEef VAN SOLDATE
}

Kol H.A. Kotzé*

\author{
"There are three types of lies: Lies, damn lies and statistics."
}

In this article five views are expressed.

1. Typical, quantitative sociological practices are not ideal to foster an understanding of man's cohabitation.

2. A new study of cohabitation or another technique of becoming acquainted with groups is needed.

3. The military is specially suited to the earlier (mal-?) practices due to its orderly structure military sociology was fraught with the earlier stereotype practices.

4. The new approach to study is one of actually experiencing and understanding, rather than description and declaration.

5. The military (especially the SA Defence Force) is well-suited to the new approach.

\section{Inleiding}

Saamleefstudies probeer die aard en kwaliteit van mense se belewenisse in groepe te ontleed. Soldate leef in groepe. Hulle word as spanne opgelei en veg in pelotons, eskaders, brigades ens.

Ons in die Weermag is bevoorreg om groepsgedrag te kan reël met behulp van formele sosiale beheer - 'n Reglement van Dissipline. Optimale soldaataanwending lê egter steeds in die korrekte inspan van bestaande of gegewe motiverings. Om hierdie motiverings, houdings en optrede van groepe te kan verstaan, is reeds vir meer as ' $n$ eeu die onderwerp van studie van sosialis (Goodman en Max, 1978:72).

Die doelbewuste inspan van die sosiologie om antwoord aan politici, ekonome, topbestuur en generale staf te verskaf, was miskien juis een van die oorsake waarom die sosiologie so teleurstellend "presteer" het (Hughes, 1980: 14). Die sosiologie moes gebruik word om mense beter te kan gebruik. Die mens is as 'n "ding", 'n "masjien" aanvaar en die sosiologie is ingespan om die regte knoppie of hefboom te vind om die masjien optimaal te laat loop. Dit het gelei tot 'n toegepaste oriëntasie en kortpaaie soos meningsopnames en houdingspeilings wat vinnige leiding aan bestuur moes gee tov spesifieke besluitneming. Dit het op sy beurt gelei tot aanskoulike en indrukwekkende aanbieding van resultate. Kleurvolle histogramme en vereenvoudigde grafieke moes aan die behoeftesteller voorgelê word. Byna soos wat 'n strafkursusaanbieding met oorlegte en transpirante soms die inhoud totaal ondergeskik aan die vorm maak, só het sommige sosioloë die tegniek en sogenaamd "oorsake" verabsoluteer. Die feit dat ingewikkelde sameloop van omstandighede in 'n spesifieke situasie tot sekere groepsgedrag aanleiding kan gee, is dikwels geïgnoreer.

Maar daar is ander oorsake vir hierdie onvoldoende kennismaking met en wanvoorstellings van groepsinteraksie.

\section{Kennisverkryging of data-insameling}

Saamleefstudies ondervind vir meer as ' $\mathrm{n}$ eeu reeds 'n probleem: die sosiologie moes kwansuis "wetenskaplik" lyk. Die natuurwetenskap en tegnologie was 'n subsoet wat vinnig gegroei en mooi presteer het. Almal wat die "wetenskap"baadjie wou aantrek, moes die logika en metodes van die eksakte natuurwetenskappe naaap. (Hughes, 1980: 19). Sosiologie sou homself slegs as wetenskap kon bewys as hy in sy waarnemings en metings die reëls van die natuurwetenskappe so na as moontlik sou nakom. Die sosioloog se bevindinge moes kwansuis in persentasies, statistiek, grafieke en histogramme uitgedruk word.

Om by sulke indrukwekkende resultate uit te kom, moes die waarnemer eers van sy eie subjektiwiteit ontslae raak (Hughes, 1980: 27). Objektiwiteit is teen groot koste en met baie moeite in eksperimente ingehou om vooroordeel en sy- 
digheid uit te skakel. Só bevrees was die eksperimenteerder dat hy van subjektiewe betrokkenheid by sy resultate beskuldig sou word, dat hy mense se gevoelens, gesindheid, houdings en allerhande abstrakte eienskappe probeer kwantifiseer het. Numeriese waardes is toegeken aan groepsmoreel, lojaliteit en houdings, Vraelyste, skedules en metingskale moes opgestel word sodat "veranderlikes" by mense en groepe, elektriese stroom, temperatuur en massa gemeet kan word. Sogenaamde wetenskaplikes het in hul strewe na wetenskaplikheid die mens uit die sosiologie ge-wetenskap.

Vandag besef sosioloë dat dié omskepping van menswees in data en syfers, van kwantitatiewe sosiologie in ' $n$ groot mate 'n vormwetenskap gemaak het. Dié strewe na 'n onbetrokke afstandsbeskouing het wel gelei tot interessante tegnieke en meetinstrumente. Maar is die antwoorde wat ons gekry het "mensantwoorde" of rekenaaruitdrukke? In die strewe na vorm het die inhoud, die menswees, die mens self uit die sosiologie verdwyn. Soos 'n chemikus wat só besig is om sy retorte te verstel en proefbuise te kook dat hy nie agterkom dat hy water ipv soutsuur ontleed nie!

Elkeen het seker al daardie onbevredigende gevoel gekry nadat hy of sy 'n sosiologiese vraelys ingevul het: die gevoel van: "Ek het dan nog glad nie gesê hoe ek voel nie!". Die vrae is dikwels só bewoord dat ek graag vir die vraesteller sou wou sê: "Maar as hy dit só vir my vra, verstaan jy nie my omstandighede nie! Kan ek asseblief nog 'n vraag van my eie byvoeg en dit beantwoord?

Maar die vraelys moet ongelukkig dienstig wees aan 'n rekenaar en antwoorde op "oop" vrae kan nie so maklik geprogrammeer word nie. Daar is nie tyd en plek vir elkeen om sy eie antwoord te gee nie. Hy moet maar kies uit die vier of vyf, benaderings wat ek as sosioloog maak. Of hy moet mý regstellings op 'n negepuntskaal takseer.

En selfs as die sosioloog "oop" vrae stel en dit met groot geduld ontleed, is die verskillende wêrelde waarin navorser en respondent leef só ver uit mekaar dat gebrekkige kommunikasie tydens 'n onderhoud of opskrif nog nie die kwaliteit van groepsbelewenis kan oordra nie. (Hughes, 1980: 98).

Nee, hierdie soort sosiologiese praktyk is soos ' $n$ vlinder wat van een blom na 'n ander fladder, vir 'n kortstondige oomblik 'n bietjie nektar by elk inneem en uiteindelik ' $n$ klomp wurms voortbring wat tot blom en vrug se ondergang lei.

\section{'n Vars windjie in hedendaagse sosiologie}

Dis maklik om objektiwistiese en kwantitatiewe kennisversameling te kritiseer. Wat van 'n alternatief?

Ten eerste moet besef word dat 'n sosioloog ook mens is. Daarom is objektiwiteit onmoontlik. Omdat die navorser terselfdertyd subjek (mens) én objek (mens) van die navorsing is, is die begrip intersubjektiwiteit eerder ter sprake (Alant et al, 1981: 16). Om tot werklike intersubjektiewe ontmoeting met ' $n$ medemens of groep te kom, is ' $n$ aangesig-tot-aangesig belewenis van omstandighede en die deel (sharing) van ervaringe nodig. Werklike begrip, gebaseer op 'n langdurige, intieme meeleef met die onderwerp van studie, bring insigte mee wat afstandskommunikasie nooit na vore kan bring nie. Die ideaal is dialogiese kommunikasie in plaas van onderbroke, eenrigtingkommunikasie (Alant et al, 1981: 15). Trouens, in baie opsigte is die vraelys wat so 'n gewilde sosiologiese tegniek was en nog is, vergelykbaar met massakommunikasie:

- Dit word ook vermenigvuldig deur 'n kragtige medium (die drukpers).

- Dit word deur spesialiste (sosiologiese joernaliste!) saamgestel.

- Alhoewel terugvoering oënskynlik die doel is word terugvoering beperk agv die vooraf-gestruktureerde aard van die vraelys - net soos massakommunikasie terugvoering beperk.

- Soos die massamedia word die inhoud van die vraelys deur burokrasie, maatskappy, topbestuur of politici bepaal (Van Schoor, 1978: 42).

Daarom is daar ' $n$ besliste neiging by moderne menswetenskaplikes om daarteen te waak om op grond van onpersoonlike kommunikasie, mense se houdings te beoordeel en groepe se interaksie hiervolgens te takseer. Deur middel van deelnemende waarneming moet die sosiloog of navorser liewer deel word van 'n situasie, dit saam met die deelnemers beleef en onderliggende motiverings en gesindhede verstaan (Cole, 1980: 77).

Persoonlike interpretasie van 'n alledaagse situasie deur 'n sogenaamde leek, is nie minder wetenskaplik of minder geldig omdat hy dit nie in vaktaal of syfers kan uitdruk nie. Trouens wat is die betekenis van groepinteraksie anders as so- 
siologie? Die probleem is om daardie kennis binne die situasie te tap en op só 'n wyse te interpreteer dat werklike ervarings begryp kan word (Alant et al, 1981: 16-17).

Die sleutelwoorde in die nuwe benadering is deelname, meelewing, interpretasie en dialoog eerder as objektiwiteit, meting, beskrywing en verklaring.

Moontlik het ons demokratiese verwysingsraamwerk ons ingedwing in die tipiese verklarings dat sê "60\%. van die kompanie toon 'n positiewe gesindheid teenoor die plaaslike bevolking "of" $90 \%$ aanvaar hul goeie oordeel". Sulke stellings kan baie meer sinvol geinterpreteer word as 'n spesifieke peloton se houdings en optrede binne die leierskapsituasie, tydens 'n uitputtende patrollie in ' $n$ spanningsatmosfeer deur ' $n$ pelotonlid self beleef word. As só 'n lid oor genoeg kennis beskik om sy eie en sy makkers se selfkennis te verwoord, is sy waarnemings ' $n$ skat van werklike sosiologiese kennis. (Scholtz, 1963: 231-49). Hipoteses moet nie voorafvervaardig word nie. Die navorser moet as't ware sy hipotese ook eers beleef en dit dan deur verdere belewenis en waarneming bevestig of weerlê (Cole, 1980: 91)

\section{Militêre sosiologie}

Alhoewel nie maklik in die literatuur te identifiseer nie, is die militêre sosiologie reeds ' $n$ erkende dissipline. Baie studies is geklassifiseerd en maak weinig bydrae tot breër sosiologiese teorie. Tog is bv. groepsdinamika-navorsers nie skaam om die militêre infrastrukture te gebruik óf dit te erken in hul werk nie (Shaw, 1981: 223).

Oëskynlik het ondersoeke deur akademici op militêre terrein weerstand by VSA-universiteite tydens die Vietnam-ooorlog ondervind. Dit het egter nie onafhanklike militêre sosioloë weerhou van samelewingsrelevante navorsing nie. Ook in die SAW is Rade van Ondersoek na spesifieke probleemsituasies en algemene moreelstudies. Alhoewel dit selde of ooit sosiologiese teorie verkry, is oortredings en beweerde wangedrag soms verbasend relevant as sosiologiese studies.

Die militêr leen hom by uitnemendheid tot die kwantitatiewe soort navorsing wat vroeër bespreek is. Die militêr is 'n ordelike, hiërargiese sisteem. Omdat sosiologiese ondersoeke langs bevelskanale bestuur kan word, is dit makliker as in 'n swak gestruktureerde gemeenskap om sê vraelyste te versprei en ingevul te kry. Groot getalle troepe, naamlyste en rekords vergemaklik steekproeftrekking en stratifikasie (kategorisering). Onkoste aan veldwerk is minimaal. Troepe is dikwels in basisse gekonsentreer. goeie dissipline laat maksimum responsie toe. Trouens, as Skutter $X$ in die hospitaal is, sal sy korporaal maklik vir Skutter $Y$ opdrag gee om somaar namens $X$ sy vorm ook in te vul!

Die wesenlike gevaar is dat hierdie ideale omstandighede om statistiek te bekom, die Weermag die slagoffers van die steriotipe sosiologiese skool van kwantitatiewe navorsers kan maak. Gebruikers en topbestuur bevraagteken selde die metodologie en tegnieke. Hulle soek net antwoorde.

Dit is egter moontlik om ook die "nuwe" benadering van kwalitatiewe belewenisstudies ook binne die Weermag toe te pas. Die SAW met sy dikwels kundige burgermagmannekrag bied ook hier geleenthede om die beter benadering van interpretasie van die werklike saamleefervarings van troepe, op versigtige wyse toe te pas.

\section{Kwalitatiewe navorsing binne SAW- verband}

Die mees algemene manier om dialogies en inter-subjektief tot begrip van 'n sosiale situasie te kom, is by wyse van deelname en waarneming. Die gedagte sou bv. in militêre milieu beteken dat die navorser deel word van 'n peloton troepe of kanonbediening wat alle fasette van groeplid te wees, saam met die groep beleef. Dit sou voordeel hê as die peloton nie eens bewus was daarvan dat hulle onder waarneming is nie. Dit is egter nie essensieel dat navorsing klandestien moet geskied nie.

Die proses is natuurlik tydsaam en 'n vlugtige besoek of enkele begeleide patrollie is hoegenaamd nie die gedagte nie. Die navorser moet 'n intern-aanvaarde en natuurlike soldaatrol speel. Hy moet oor dieselfde militêre vaardighede as die gemiddelde pelotonlid beskik. Hy moet ' $n$ integrale deel van die peloton wees en nie 'n laatkommer of toegevoegde met spesiale voorregte nie. Sy waarnemings moet onopsigtelik aangeteken of selfs gememoriseer word. Hy moet self toegang en geleentheid tot alledaagse gesels met lede verkry. Hy moet só toeganklik wees dat intieme probleme, vertroulike hou- 
dings, voorkeure en afkeure teenoor hom uitgespreek kan word.

Voordat iemand sê dat hierdie navorser 'n soort engel uit die hemel moet wees, kan vermeld word dat enigiemand met sosiologiese agtergrond wat goed voorbereid is en oor redelike menseverhoudings beskik, voldoende toegang en insig behoort te hê om tersaaklike waarnemings te kan maak.

Dit sou uit die aard van militêre problematiek onprakties wees om 'n ope opdrag (vrye keuse) tov waarneming aan sulke navorsers te gee. Leiding is nodig in 'n breër studierigting bv. "Neem lojaliteit teenoor die genietroepbevelvoerder waar met spesifieke verwysing na uitvoering van opdragte" of "Evalueer die ervaring van die stormgroep vir 'n aanvalsmag deur deelnemende waarneming by wyse van inter-subjektiewe dialoog".

Hierdie tipe leiding kan in oorleg met die formasiebevelvoerders of ander kundiges gékoördineer word vir 'n navorsingsentrum terwyl individuele navorsers onafhanklik vir (sê) drie-maande tydperkte by wyse van deelneming, waarneming doen. Na afloop van die tydperk kan waarnemings met mekaar vergelyk word maar gevalle van bevredigende responsie en hoë kwaliteitsgraad moet op eie meriete aangeteken word.

Tov aanbieding van die resultaat is dit gestel as 'n kort, geskrewe verslag van optrede en waarneming wat aan militêre leiers voorgelê word. Primêre terugvoer moet egter geskied by wyse van ' $n$ mondelinge voorligting aan senior offisiere in 'n ontspanne atmosfeer met genoegsame tyd vir bespreking. Eie interpretasies van die navorser moet sonder verskonings aangebied word. Redes vir optrede en houdinge moet gegee word maar almal moet daarop bedag wees dat die navorser nie verklarings, tendense, voorspellings of kitsoplossings sal aanbied nie. Hy kan slegs begrip vir troepe se optrede probeer oordra. Dit spreek natuurlik vanself dat geen dissiplinêre stappe uit die waarnemings mag voortspruit nie. Die navorser se vertrouensposisie moet beskerm word. Hy is nie 'n luistervink of teeninligtingsagent nie.

\section{Slot}

Hierdie artikel het nie ten doel om organisasies vir navorsing te skep nie. Sonder om addisionele mannekrag te verkry behoort ons burgermagstelsel egter ' $n$ goeie basis te vorm waarop 'n stelsel van kwalitatiewe navorsing binne die SAW gebou kan word.

Verder moet spesifiek gewaak word teen die vinnige soort ondersoek wat gister reeds voltooi moes wees en 'n skyn van wetenskaplikheid wat geput word uit 'n lang vraelys en twyfelagtige verklaring van die saamleef van soldate, gegrond op statistieke en kousale verbande.

*Kolonel H.A. Kotzé, SA Stafkorps, het in 1963 in die Weermag geattesteer. Hy verwerf die graad B Mil (BSC) aan die Militêre Akademie te Saldanha in 1966. Hierna beklee hy instrukteurs-, staf- en bevelsposte in die lugafweerartillerie. Hy slaag in 1975 die SA Leër Bevel- en Stafkursus waarna hy algemene poste, onder andere in die operasionele gebied, vul. Hy verwert 'n BA-graad met hierdie rigtings as hoofvakke aan UNISA in 1982.

\section{Bronne}

Alant, C.J. et al. On societics and societal existence. Johannesburg, Mc Graw Hill, 1981.

Cole, S. The sociological method. Rand McNally College publishing company, Chicago, 1980.

Goodwin, N. \& Max, G.T. Society today. CRM/Randan House, New York, 1978.

Hughes, J. The philosophy of social research. Longman, London, 1980.

Schutz, A 'Concept and theory formation in the social sciences' in $M$. Natanson (red): Philosophy of the social sciences. New York, Random House, 1963, pp 231-49.

Shaw, M.E. Group dynamics: The psychology of small group behaviour. Mc Graw-Hill, New York, 1981. 